\title{
10
}

\section{Results Rather than Indulgences}

The important thing is to solve the problems we face-not who does it or

what looks good. In order to address the important issues properly, prioritization is key. This means giving priority to material sustainability issues, which in turn requires fruitful communication with the company's stakeholders in a way that convinces them that the company is taking appropriate and effective steps toward more sustainable business models.

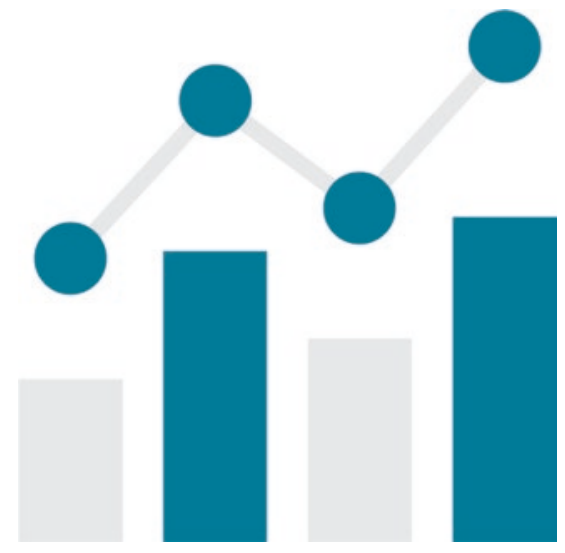

Fig. 10.1 Results Rather than Indulgences

(C) The Author(s) 2018

S. Jørgensen, L. J. T. Pedersen, RESTART Sustainable Business Model Innovation, Palgrave Studies in Sustainable Business In Association with Future Earth, https://doi.org/10.1007/978-3-319-91971-3_10 


\subsection{With an Eye on the Ball}

Do you buy ugly food? Every year, citizens in the European Union throw more than 88 million tons of food that could have been eaten, which is equivalent to more than $170 \mathrm{~kg}$ per person (Stenmarck et al. 2016) (Fig. 10.1).

By some estimates, we throw away approximately 42 percent of all the food we buy, and the greenhouse gas emissions, water consumption and the overall environmental impact associated with food production are enormous. Food waste is a global problem, and in response to this problem, the French retail chain Intermarché initiated the campaign "Inglorious Fruits and Vegetables". It started selling smoothies made of misshapen fruit and vegetables, accompanied by colorful and eye-catching posters depicting the weird ingredients. Customers liked the taste as well as the idea, and the company consequently developed the concept further so that customers were offered the "ugly" fruits in the store at a 30 percent discount. During the first two days alone, Intermarché sold tons of ugly fruit and vegetables, and the campaign received great attention worldwide.

Through this clever campaign, Intermarché succeeded with several things at once: It managed to change customers' ingrained habit of steering away from ugly food products. It managed to reduce food waste in its stores. Thus, it also reduced its costs related to managing food waste and, instead, sold the products at a lower, but still acceptable, price. Not at least, it received considerable positive publicity and attention around the campaign and its message.

Intermarché turned the problem on its head when it began to promote and sell products with imperfections. If companies are to succeed with aligning sustainability and profitability, it will require also looking at the sustainability problem as an opportunity (e.g., Porter and Kramer 2011). This may allow for developing solutions and technologies that can solve problems the company itself may not have been part of creating in the first place. Newlight did this when it realized that it could use excess $\mathrm{CO}_{2}$ in the atmosphere to produce plastic. Interface did it when it addressed its own shadow and changed its production processes in a way that also 
reduced costs. Norsk Gjenvinning did it when it conducted an extensive turnaround and cleanup in its own backyard, to get rid of the troubled conditions in its supply chain.

In the last few decades, the majority of companies around the world have put corporate social responsibility (CSR) on their agenda. Part of the criticism directed against the CSR phenomenon is that it has often been about acting in ways that look good or that give stakeholders what they ask for (see, e.g., Visser 2011). This is not always the same as implementing impactful changes in business models to promote social and environmental performance (Eccles and Serafeim 2013). In particular, there has been considerable conflation between CSR initiatives that actually relate to the company's core business and those that are more peripheral, such as various types of philanthropy (e.g., Burke and Logsdon 1996). For companies that are committed to creating real change and that aim to align sustainability and profitability, it is essential that sustainability efforts are oriented to creating the right kind of results, rather than being a form of indulgence that does not really influence the business model (Khan et al. 2016).

\section{The Road to Being Sustainable and Profitable}

Much research has been conducted on the question of how to align sustainability and profitability (see, e.g., Khan et al. 2016; Kang et al. 2016; Eccles et al. 2015; Flammer 2015; Edmans 2011; Margolis et al. 2007; Orlitzky et al. 2003; Waddock and Graves 1997). However, a fundamental problem is that this stream of research often compares apples and oranges. First, many studies disregard the distinction between efforts aimed at promoting corporate social and environmental performance in ways that are tied to core business and efforts that are more peripheral to the company's strategy and operations (cf. Khan et al. 2016). Second, many studies have failed to distinguish between the types of efforts and practices that characterize companies that succeed in becoming more sustainable and those that do not. 
We previously mentioned a study conducted by Robert G. Eccles and his colleagues (Eccles et al. 2014), which sheds light on the relationship between sustainability and profitability. The study builds on previous research, which has suggested a small but positive difference between more and less sustainable (or responsible) companies and that investments in sustainability have a positive but diminishing effect on financial performance. The study by Eccles and his colleagues is perhaps the single study that so far has presented the strongest evidence for a positive relationship between sustainability and profitability. Moreover, it reveals the organizational characteristics of these companies that set them apart from others. To dig deeper into the underlying mechanisms of the relationship between sustainability performance and financial performance, it is important to have insight into the efforts and practices that companies can employ in practice. Let us take a closer look at them.

Simply put, achieving profitability involves increasing revenues, reducing costs or both. By extension, this applies to the relationship between sustainability and profitability. For sustainability efforts to pay off, they must affect the company's bottom line by influencing revenues and costs directly and/or indirectly. Some efforts have a direct effect on the bottom line, for example, when Intermarché manages to sell ugly fruits and vegetables that the company would otherwise have had to pay to dispose of. Other efforts have a more indirect impact on the company's performance. For example, this is the case if competent workers choose Intermarché as an employer because of the positive attention to the campaign, and that Intermarché in turn uses this expertise to perform better. In Fig. 10.2, we show various effects of this type. We distinguish between efforts influencing the upside positively and efforts that reduce the downside. Furthermore, we distinguish between efforts that have a direct influence and those that have an indirect influence on the company's performance.

Figure 10.2 illustrates how sustainability efforts can promote profitability by contributing to higher revenues and/or lower costs. We denote the indirect upside intangible assets, and it shows that sustainable companies, for example, can improve their reputation and increase trust and 


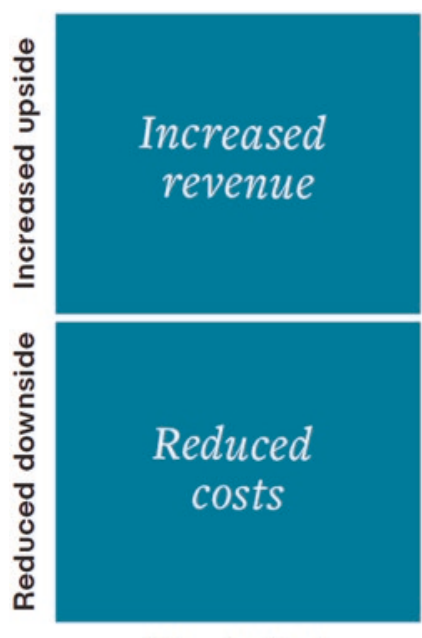

Direct effect

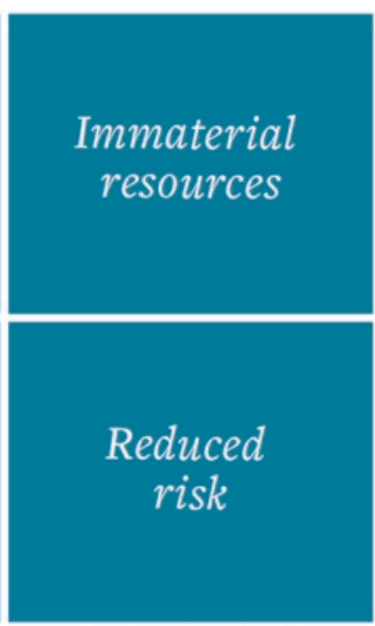

Indirect effect

Fig. 10.2 How sustainability influences the company's performance (based on Esty and Winston 2009)

confidence among its key stakeholders, which in turn may translate into better performance. Sustainability efforts can influence the indirect downside by potentially reducing the company's risk, which can lead investors or lenders to give favorable financing conditions. This can, for instance, be due to a more circular business model that reduces the company's supply risk for key resources and input factors.

These four effects-higher revenues, lower costs, increased access to intellectual resources and reduced risk — may perhaps not belong in distinct categories. A better reputation can influence customers' inclinations positively and reduced risk could lead to lower interest rates on loans, thereby reducing costs in the short term. However, by differentiating between upside and downside effects, and between direct and indirect effects, it becomes easier for decision makers to see how investments in sustainability may also have effects beyond direct influence in the short term. Presumably, the most important effects will emerge over time-for example, increased trust could in turn make a company more attractive to collaborators, employees, investors and other stakeholders (Jørgensen et al. 2018). 
Intermarché has reaped several of the benefits mentioned above. After the launch of the ugly fruit and vegetables campaign, the company experienced both an increase in the upside effects and a reduction in the downside effects. Ugly food became surprisingly popular with customers, and perhaps the most important effect was the massive media coverage worldwide. This also led supermarkets on several other continents to imitate the campaign, which in turn gave Intermarché even more attention. From a pure cost perspective, Intermarché reduced its costs associated with food waste and waste management. Finally, it succeeded in selling products that would otherwise end up in landfills, and, by its own account, the company claims that the number of customers in its stores increased by almost 25 percent in this period. However, perhaps the most striking consequence of the campaign-not at least in a sustainability performance perspective-is that the company has been successful in changing consumer behavior: While customers were previously not willing to eat ugly food, Intermarché found a clever way to stimulate greener consumption habits among its customers. This is a powerful opportunity for companies, and such mechanisms can obviously be used to encourage more sustainable consumption (see, e.g., Lehner et al. 2016).

The ugly food of Intermarché is a clear example of how sustainability efforts - in this case, reduced food waste - may cause financially advantageous consequences for a company. Such "low-hanging fruit" (!) cannot necessarily be found in all industries, but companies in any industry should be able to identify some opportunities to align sustainability and profitability in their operations. As the story of Intermarché shows, there are some important steps on the road to aligning sustainability and profitability. First, to identify material sustainability problems in the current business model: What types of light and shadow does the company cast through its current operations? Second, to map the stakeholders in the company's surroundings on which it depends. Which interests are at stake and which of them must be taken into account in the design of the business model? And finally, to find ways of assigning resources to sustainability efforts that are valued by stakeholders in such a way that they either directly or indirectly affect the 
company's revenue, costs, intangible resources or risk in a desirable manner. The process we describe here, however, can become costly if the company does not prioritize in a fruitful way. A characteristic of the most successful companies is that they are able to prioritize in appropriate ways in their sustainability efforts, which we will consider in the following.

\subsection{Prioritize What Matters}

How do you know if the resources you have allocated to sustainability efforts lead you toward the goals you have set?

We live in a globalized world, but some companies are more global than are others. Every single day, more than 2.5 billion people around the world use one of Unilever's products. If you have a cup of Lipton tea, wash your hands with Dove soap, cleanse your ears with Q-tips or treat yourself to a bowl of ice cream from Ben \& Jerry, you have used one of Unilever's many brands. This company is almost as present in American supermarkets as in small local markets in Southeast Asia. Unilever has set a goal of improving the health, diet and nutrition of one billion people by the year 2020 . The company also stated a very ambitious target to halve the environmental impact of its products. It thus aims to succeed with so-called green growth, which implies increasing productivity and solving social issues while reducing its environmental impact. These objectives are embodied in Unilever's corporate strategy, which is named the "Sustainable Living Plan".

Dedicated work lies behind this strategy, whereby Unilever systematically considers which problems to solve, for whom and why. In these analyses, Unilever maps what is important both for its own profitability and for the interests of its stakeholders. Such analyses are often called materiality assessments. To assess materiality involves identifying salient social and environmental issues that the company faces and prioritizing them with regard to their importance from economic, social and environmental standpoints. The key is therefore to draw awareness to the issues that are so important that they cannot be ignored and that can 
influence the decisions of the company's stakeholders (see, e.g., Eccles et al. 2012). Investors make the decision of whether to invest in the company; customers decide whether to buy the company's products and services; employees decide if they want to work for the company and so on. Generally, companies must take great care in addressing material sustainability issues, while they may place less emphasis on those that are less material (Khan et al. 2016). This may seem like a trivial point but, in practice, many companies prioritize sustainability efforts that relate to core business to a very low degree. Instead, they may imitate other companies' sustainability efforts regardless of their relevance and salience for the company's business model or choose to focus on "low-hanging fruit" with little impact. Figure 10.3 illustrates what a materiality assessment looks like, with issues that are important for stakeholders on one axis and those that are important for the company on the other.

As shown in the figure, such an analysis makes it is possible to rank and prioritize sustainability issues. In the bottom left corner, we find

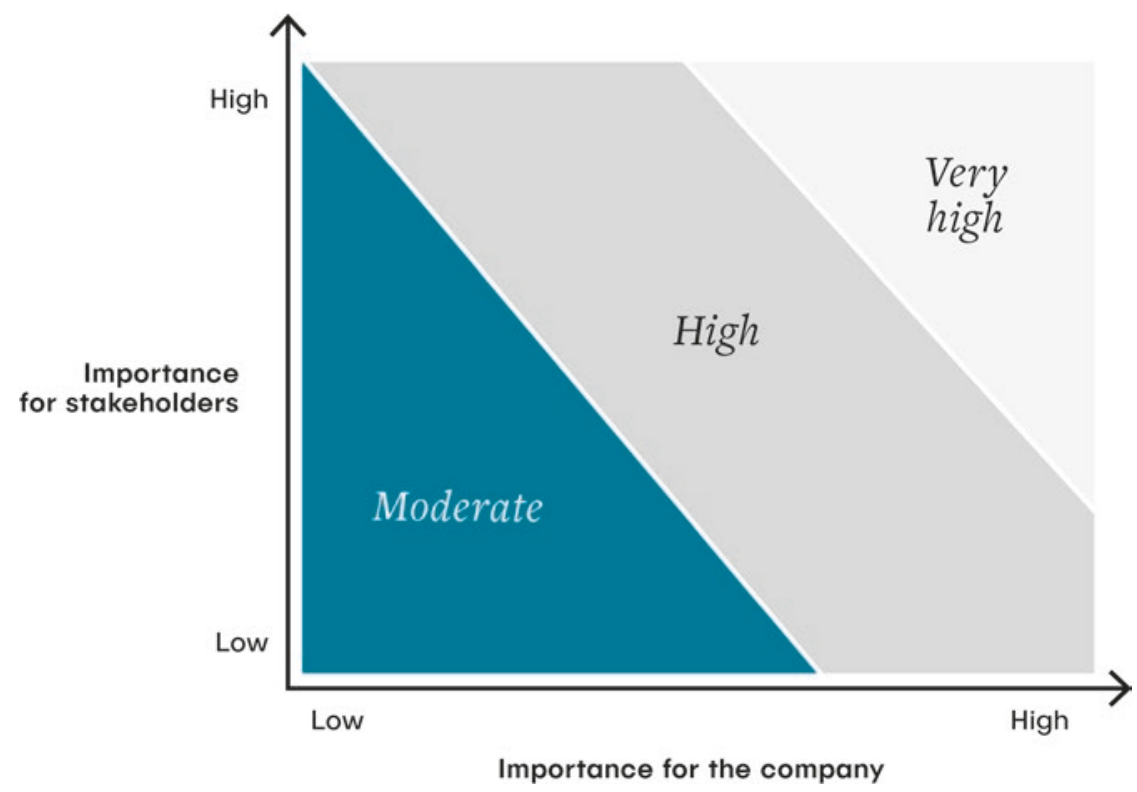

Fig. 10.3 Which issues are material—for the company and for its stakeholders? 
moderately important sustainability issues. Issues further up and to the right in the diagram are gradually more important, and companies will typically try to prioritize issues that are ranked as high or very high. Such an analysis is not about asking whether improving sustainability performance makes companies become more profitable but about what kinds of sustainability efforts that may promote profitability. The first question is which efforts should be undertaken. The second question is how to know whether the resources allocated to sustainability efforts lead toward attaining the goals set by the company and if stakeholders appreciate the efforts.

It should be noted that the company and its stakeholders might have different perceptions of the reality of sustainability issues facing the company. For example, there is apparently still widespread fear of antibiotics in farmed salmon among the customers of such products. Numbers put forward by fish-farming companies, however, suggest that antibiotics are largely eradicated in farmed fish and have been for a long time, while problems such as fish lice and escapes from fish farms are considerably more urgent sustainability issues to address. Seen from the companies' perspective, then, its customers are perhaps worried about the wrong problems and should instead demand that companies address problems like fish lice and fish escape. This also suggests how working with materiality assessments can be valuable for other reasons than prioritization. The case of antibiotics in fish farming suggests that the fish-farming companies have not succeeded in communicating to customers that the antibiotics problem is largely resolved. Thus, they can take further steps to inform customers about this, for the benefit of both parties.

Unilever uses materiality assessments extensively. In its corporate strategy, Unilever has identified 191 issues, such as animal welfare, workers' pay and greenhouse gas emissions. These issues are distributed within 38 topics, such as climate change and fair trade. The 38 subjects are moreover distributed across five major focus areas: (1) improving health and wellbeing, (2) reducing environmental impact, (3) enhancing livelihoods, (4) responsible business practices and (5) wider sustainability topics. Within each of these five focus areas, the company can prioritize the issues that will likely lead to the most desirable results by solving problems with which stakeholders are concerned and that are to the benefit of the company. 


\section{Is It Profitable to Solve the Most Important Problems?}

You might ask if materiality analyses are worthwhile conducting. An interesting study conducted by a group of Harvard researchers led by George Serafeim shows that such analyses may have substantial value (see Khan et al. 2016). The study digs deeper into what kind of sustainability efforts promote financial performance by differentiating between more and less material sustainability issues. The study categorizes the sustainability efforts of a wide range of companies in accordance with a materiality assessment based on the Sustainability Accounting Standards Board (SASB) standards. This enables the researchers to compare companies with respect to their priorities based on materiality and assess how these priorities in turn influence financial performance. The study reveals that the key is to allocate resources strictly to sustainability efforts that relate to material sustainability issues.

This implies that companies that invest in solving material sustainability issues experience greater positive financial performance effects than do both those that do not make such investment and those that invest in solving both material and immaterial issues. This has two aspects: First, it shows that solving the actual problems that influence stakeholder interests is what is rewarded in the market. Second, it shows that the amount of resources allocated to sustainability efforts is not the key. Rather, what matters is how these funds are actually used. There are many good intentions in dealing with social and environmental issues, but to solve the actual problems, resources must be used in a focused and smart manner on the material issues. Moreover, in order to identify and manage these problems, it is necessary that the company constantly monitors and engages with stakeholders and strictly prioritizes the most material issues.

An example of a company using materiality assessments in this way is Aker BioMarine, a Norwegian biotech innovator and Antarctic krill-harvesting company with a global presence. The company is the world's leading supplier of krill products, which are Omega-3-rich and used for human and animal nutrition purposes. The company has worked with integrating sustainability into the company's business model, and materiality assessments were central to this work. The basis for the sustainability 
strategies, however, were the UN Sustainable Development Goals (SDGs). The company selected four of the 17 SDGs as its strategic priorities:

- End hunger, achieve food security and improved nutrition and promote sustainable agriculture

- Ensure healthy lives and promote well-being for all at all ages

- Ensure sustainable consumption and production patterns

- Conserve and sustainably use the oceans, seas and marine resources for sustainable development

The selection of these goals as strategic priorities thus gave the company, and its sustainability director Cilia Holmes Indahl, further direction in the assessment of material sustainability concerns that allowed for integrating appropriate sustainability efforts into the business model of the company, in a way that aligned financial and sustainability-related objectives.

\section{Let Sustainable Business Flourish!}

For sustainability efforts to promote corporate financial performance, they must lead to two things at once. On the one hand, they must help the company cast less shadow and/or shed more light, whether because the company reduces its own externalities, or because it helps other companies reduce theirs. On the other hand, they must promote the company's financial performance by directly or indirectly increasing revenues or reducing costs in the shorter or longer term.

There are several ways companies can succeed with this. First, a company can offer new or improved types of value to its customers, which may lead customers to prefer its products or services. Second, the company can attract resources that would otherwise not have been available to it, such as employees, investors or partners who are attracted by the company's sustainability profile. Third, the company's sustainability efforts can render it able to perform value-adding activities that it could otherwise not have carried out, which can be a consequence of attracting 
new and valuable resources or partners. Fourth, the company can take advantage of opportunities in product markets that otherwise would have been inaccessible, for example, by attaining a position in the market or a reputation that makes the company more competitive. This all involves expanding the opportunity space of the company to the extent that welldesigned sustainability efforts can lead to the company to exploit new business opportunities or enhance its position for exploiting existing business opportunities.

There are numerous scientific studies that support such mechanisms and that suggest that more sustainable companies can achieve unique competitive advantages. First, highly qualified employees are increasingly attracted to companies they perceive to be more sustainable, and they are often even willing to work for relatively lower wages (see, e.g., Koys 2001; Harter et al. 2002; Frank 2004; Turban and Greening 1997). Other studies show that the responsible companies have fewer capital constraints (Cheng et al. 2014). This is interesting in the context of how financial markets are developing, for instance, as one of China's largest banks is now screening all corporate loan applications for climate risk. Furthermore, there is research showing that customers-whether they are companies or individuals - are more trusting toward companies they deem responsible, which in turn may promote economic activity and reduce transaction costs (Zsolnai 2004; Jørgensen et al. 2018; see also Bartling et al. 2013). In some product and service categories, customers prefer companies they perceive as being responsible, and under some circumstances may be more loyal to these companies (see, e.g., Sen and Bhattacharya 2001; McWilliams and Siegel 2000; Bollen 2007). A stronger stakeholder orientation is moreover associated with being more innovative (Flammer and Kacperczyk 2015).

In addition to this, companies that are in extensive contact with its stakeholders may develop greater capacity to absorb market changes at an early stage. This may in turn help promote their ability to innovate, and recent research suggests that there is a positive correlation between stakeholder engagement and innovation (Flammer and Kacperczyk 2016). A final driver for investment in sustainability is the expectation of future regulations. For companies that proactively and voluntarily reduce their shadows, there may be a first-mover advantage in the event of future 
regulations (cf. Nehrt 1998). These are all mechanisms through which sustainability efforts directly or indirectly may promote companies' financial performance. It should be noted that there are also several studies that indicate that these effects are smaller and even negligible. However, the conclusions depend highly on what is measured and what time horizon is assumed.

Whether you make an optimistic or more moderate estimate of the potential positive effects of sustainability efforts for companies, emphasizing results rather than indulgences and prioritizing material issues are both essential for companies that take sustainability seriously. What the knowledge about sustainability efforts and the consequences thereof also suggests is that companies should better adapt their efforts in line with what they are trying to achieve and for whom. This begs the question: What do the drivers of sustainability efforts imply for how to design the efforts?

To answer this question, it may be useful to distinguish between "push" and "pull" factors for companies' investments in sustainability efforts. These factors, respectively, reflect the negative aspects of the current business model, which "push" the company toward more sustainable solutions, and the positive aspects of an alternative, more sustainable business model, which are attractive enough to "pull" the company toward change. In Table 10.1, we distinguish between these two types of factors that can act as drivers of sustainability efforts. In addition, we provide examples of such forces, respectively, associated with product markets, factor markets, capital markets, the regulatory environment and the socio-cultural environment (see also Horbach et al. 2012).

As the overview shows, there may be many factors driving the company toward becoming more sustainable. How a company prioritizes in order to achieve desired results will be a function of the kind of company it is. For example, some companies will be more influenced by trends for sustainable lifestyles, as is the case within the food industry and in mobility services. Similarly, some companies, such as financial institutions and aquaculture companies, are significantly more exposed to regulations. In addition, some companies will benefit more from technological innovations that make it easier to make their business model more sustainable, such as companies that can use 3D printers to reduce the need for transportation in their supply chains. 
Table 10.1 "Push" and "pull" factors in sustainable business model innovations

\begin{tabular}{|c|c|c|}
\hline & "Push" factors & "Pull" factors \\
\hline $\begin{array}{l}\text { The product } \\
\text { market }\end{array}$ & $\begin{array}{l}\text { Competitors offer } \\
\text { attractive products and } \\
\text { services that are more } \\
\text { sustainable. }\end{array}$ & $\begin{array}{l}\text { Customers demand more } \\
\text { sustainable solutions. } \\
\text { Opportunity to differentiate. }\end{array}$ \\
\hline The factor market & $\begin{array}{l}\text { Key inputs become scarcer } \\
\text { and thus more expensive. } \\
\text { Demands from partners. }\end{array}$ & $\begin{array}{l}\text { Highly qualified employees } \\
\text { are attracted by the more } \\
\text { sustainable companies. } \\
\text { New technologies make it } \\
\text { easier and less costly to } \\
\text { become more sustainable. }\end{array}$ \\
\hline $\begin{array}{l}\text { The capital } \\
\text { market }\end{array}$ & $\begin{array}{l}\text { Requirements of owners } \\
\text { and lenders. }\end{array}$ & $\begin{array}{l}\text { Attracting long-term investors } \\
\text { with an aversion to } \\
\text { sustainability risk. }\end{array}$ \\
\hline $\begin{array}{l}\text { The regulatory } \\
\text { environment }\end{array}$ & $\begin{array}{l}\text { Threat of stricter } \\
\text { regulations or taxation. }\end{array}$ & $\begin{array}{l}\text { Achieving first-mover } \\
\text { advantage by setting the } \\
\text { sustainability standard in the } \\
\text { industry. }\end{array}$ \\
\hline $\begin{array}{l}\text { The socio-cultural } \\
\text { environment }\end{array}$ & $\begin{array}{l}\text { Pressure from key } \\
\text { stakeholder groups, } \\
\text { thought leaders, and so on. }\end{array}$ & $\begin{array}{l}\text { Trends for more sustainable } \\
\text { lifestyles. }\end{array}$ \\
\hline
\end{tabular}

These drivers will to varying degrees influence different sectors and at different times. For example, considerable stakeholder pressures and demands from customers drove big food producers to remove palm oil from their products around 2014. In Norway, the retail company Norgesgruppen argued publicly for stricter environmental regulations of Norwegian companies. This was probably, in addition to a desire for a greener economy, also done in the knowledge that it would give the company a first-mover advantage vis-à-vis its competitors. After all, Norgesgruppen had already made substantial investments to become more sustainable. In addition, the diffusion of better and cheaper solar panels has made it easier for companies in sunny areas to utilize this technology to replace a portion of their energy consumption with renewable energy. How many of the factors in Table 10.1 are applicable for the individual company, and how strong they are, will influence which sustainability issues the company prioritizes and the kinds of efforts it in turn implements. This will also be crucial for the company's ability to align sustainability and profitability over time. 
Unilever is present worldwide, and the same is true for its sustainability efforts. The company provides poor customers in Southeast Asia with access to hygiene products using decentralized sales networks in cooperation with local entrepreneurs. Unilever also initiates large water conservation and reuse measures, which it attempts to scale throughout its entire value chain. Moreover, the company transitions toward more sustainable forms of soy production in Latin America, where such production has been very ecologically harmful for a long time. Common to all the major and minor efforts implemented by Unilever, along its many value chains worldwide, is that the company has assessed the sustainability issues with regard to their materiality. Based on this, the company prioritizes the initiatives that have the greatest possible value along three dimensions: economic, social and environmental performance (cf. Elkington 1997). By doing so, the company strengthens its ability to be sustainable and profitable over time.

\section{References}

Bartling, B., Fehr, E., \& Huffman, D. (2013). Institutions and trust: Does trust generate lasting improvements in economic outcomes? Working paper, The University of Zürich, Zürich.

Bollen, N. P. (2007). Mutual fund attributes and investor behavior. Journal of Financial and Quantitative Analysis, 42(3), 683-708.

Cheng, B., Ioannou, I., \& Serafeim, G. (2014). Corporate social responsibility and access to finance. Strategic Management Journal, 35(1), 1-23.

Eccles, R. G., Ioannou, I., \& Serafeim, G. (2014). The impact of corporate sustainability on organizational processes and performance. Management Science, 60(11), 2835-2857.

Eccles, R. G., Krzus, M. P., Rogers, J., \& Serafeim, G. (2012). The need for sector-specific materiality and sustainability reporting standards. Journal of Applied Corporate Finance, 24(2), 65-71.

Eccles, R. G., \& Serafeim, G. (2013). The performance frontier. Harvard Business Review, 91(5), 50-60.

Elkington, J. (1997). Cannibals with forks. The triple bottom line of 21st century. Oxford: Capstone. 
Esty, D., \& Winston, A. (2009). Green to gold: How smart companies use environmental strategy to innovate, create value, and build competitive advantage. London: John Wiley \& Sons.

Flammer, C. (2015). Does corporate social responsibility lead to superior financial performance? A regression discontinuity approach. Management Science, 61(11), 2549-2568.

Flammer, C., \& Kacperczyk, A. (2015). The impact of stakeholder orientation on innovation: Evidence from a natural experiment. Management Science, 62(7), 1982-2001.

Frank, R. H. (2004). What price the moral high ground? How to succeed without selling your soul. Princeton, NJ: Princeton University Press.

Harter, J. K., Schmidt, F. L., \& Hayes, T. L. (2002). Business-unit-level relationship between employee satisfaction, employee engagement, and business outcomes: A meta-analysis. Journal of Applied Psychology, 87(2), 268.

Horbach, J., Rammer, C., \& Rennings, K. (2012). Determinants of eco-innovations by type of environmental impact-The role of regulatory push/pull, technology push and market pull. Ecological Economics, 78, 112-122.

Jørgensen, S., Pedersen, L. J. T., \& Skard, S. (2018). Does going green build trust? The relationship between sustainability efforts, perceived innovativeness and trust. Working paper, NHH Norwegian School of Economics.

Kang, C., Germann, F., \& Grewal, R. (2016). Washing away your sins? Corporate social responsibility, corporate social irresponsibility, and firm performance. Journal of Marketing, 80(2), 59-79.

Koys, D. J. (2001). The effects of employee satisfaction, organizational citizenship behavior, and turnover on organizational effectiveness: A unit-level, longitudinal study. Personnel Psychology, 54(1), 101-114.

Lehner, M., Mont, O., \& Heiskanen, E. (2016). Nudging-A promising tool for sustainable consumption behaviour? Journal of Cleaner Production, 134, 166-177.

Margolis, J. D., Elfenbein, H. A., \& Walsh, J. P. (2007). Does it pay to be good? A meta-analysis and redirection of research on the relationship between corporate social and financial performance. Ann Arbor, 1001, 48109-1234.

Nehrt, C. (1998). Maintainability of first mover advantages when environmental regulations differ between countries. Academy of Management Review, 23(1), 77-97.

Orlitzky, M., Schmidt, F. L., \& Rynes, S. L. (2003). Corporate social and financial performance: A meta-analysis. Organization Studies, 24(3), 403-441. 
Sen, S., \& Bhattacharya, C. B. (2001). Does doing good always lead to doing better? Consumer reactions to corporate social responsibility. Journal of Marketing Research, 38(2), 225-243.

Stenmarck, A., Jensen, C., Quested, T., Moates, G., Buksti, M., Cseh, B., \& Scherhaufer, S. (2016). Estimates of European food waste levels. IVL Swedish Environmental Research Institute.

Turban, D. B., \& Greening, D. W. (1997). Corporate social performance and organizational attractiveness to prospective employees. Academy of Management Journal, 40(3), 658-672.

Visser, W. (2011). The age of responsibility: CSR 2.0 and the new DNA of business. Hoboken, NJ: John Wiley \& Sons.

Waddock, S. A., \& Graves, S. B. (1997). The corporate social performancefinancial performance link. Strategic Management Journal, 18(4), 303-319.

Zsolnai, L. (2004). Honesty and trust in economic relationships. Management Research News, 27(7), 57-62.

Open Access This chapter is licensed under the terms of the Creative Commons Attribution-NonCommercial-NoDerivatives 4.0 International License (http:// creativecommons.org/licenses/by-nc-nd/4.0/), which permits any noncommercial use, sharing, distribution and reproduction in any medium or format, as long as you give appropriate credit to the original author(s) and the source, provide a link to the Creative Commons license and indicate if you modified the licensed material. You do not have permission under this license to share adapted material derived from this book or parts of it.

The images or other third party material in this chapter are included in the chapter's Creative Commons license, unless indicated otherwise in a credit line to the material. If material is not included in the chapter's Creative Commons license and your intended use is not permitted by statutory regulation or exceeds the permitted use, you will need to obtain permission directly from the copyright holder.

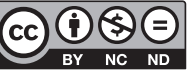

